\title{
Performance and NOx Investigation on Diesel Engine using Cold EGR Spiral Tube: A Review
}

\author{
Semin $^{1}$, Adhi Iswantoro ${ }^{2}$, Fatekhun Faris ${ }^{3}$
}

\begin{abstract}
Based the problem, many technologies invented to reduce the Emission. One of them is EGR (Exhaust Gas Recirculation). EGR is the most simpleNOx reduction by circulating potion of exhaust gas return into the combustion chamber. EGR system is often known by the name the hot EGR where exhaust gas circulation process without cooling system. This new Hot EGR system is designed by the addition of cooling system with air-cooled type. So that the circulating of exhaust gas to be cooled in advance in such that the mass of air increases.This research aims to study the performance and a reduction in NOX of diesel engine with EGR using addition of air cooling system. The experiments were used on diesel engine Yanmar TF 85-MHDI.
\end{abstract}

Keywords—cold EGR spiral tube, EGR,emission, engine performance

\section{INTRODUCTION ${ }^{1}$}

$\mathrm{E}$ missions are the biggest problem in the world. The main source of emissions is $\mathrm{SOx}, \mathrm{NOx}, \mathrm{CO}$, and HC. Emissions are very harmful for human and environment. The research about technology reduction emissions for solve this problem is already done. The technology emission reduction are Exhaust Gas Recirculation (EGR), Amonia Scrubber, Direct Water Injection (DWI), Diesel Particulate Filter (DPF).

Technology EGR is the simplest system to reduce emissions NOx. It began circulating potion of exhaust gas circulation gas return into the combustion chamber. But in the application of the EGR system has negative effect such as increasing fuel oil consumption, decreasing of perform engine, and increasing emissions Particulate Matter (PM) [1].

Brief explanation about reduction of NOx and grime in cold EGR, we can mention two important factors: firstly input load temperature reduction, lengthens combustion retardation and consequently induces more homogeneity between fuel steam and oxygen synthesis. And secondly trapped air mass in the cylinder. Input oxygen density increment will reduce dilution effect. Also in this situation cylinder pressure increment and consequently fortification of compress and combustion stroke cause effective pressure optimization which will optimize fuel consumption [2]. the manufacturing cold EGR system is very effective to reduce emissions.

From the simulation results that have been done by Nasser [3], Explained that the spiral pipes used on the EGR line can reduce pressure drop and heat transfer. It will cause an increase in oxygen mass before entering into the combustion chamber by 10 percent.

In this research will be discussed Experiment-based analysisDesign manufacturing Cold EGR by using spiral

\footnotetext{
S emin, Department of Marine Engineering, Institut Teknologi Sepuluh Nopember, Surabaya 60111, Indonesia,Email seminits@yahoo.com

AdhiIswantoro, Department of Marine Engineering, Institut Teknologi Sepuluh Nopember, Surabaya 60111, Indonesia,Email : adhi.iswantoro@gmail.com

Fatekhun Faris, Department of Marine Engineering, Institut Teknologi Sepuluh Nopember, Surabaya 60111, Indonesia,Email : fatekhunfaris16@gmail.com
}

tube channel. To reduce the increase in fuel consumption, and could reduce emissions of PM (Particulate Matter).For this will be analyzed the results of motor performance, and NOx content contained in the motor on the Cold EGR system using a spiral tube.

\section{METHOD}

\section{II.1 Formula Performance Calculations}

- Engine-output

The motor is the parameter in determining motor performance .Understanding it is been the large work motor efforts over time.

$$
\mathrm{P}=\frac{\mathrm{v} x \mathrm{i} x \cos \emptyset}{\text { eff } \operatorname{gen} \mathrm{x} e \mathrm{ff} \text { slip }}
$$

$$
\begin{array}{ll}
\text { Where : } & \\
\mathrm{P} & : \text { power }(\mathrm{kW}) \\
\mathrm{V} & : \text { voltage }(\text { Volt }) \\
\mathrm{I} & : \text { electric current (Ampere) } \\
\text { Cos } \varnothing & : 0.9 \\
\text { Eff Gen } & : \text { generator efficiency }(0.85) \\
\text { Eff Slip } & : \text { slip efficiency (calculate) }
\end{array}
$$

- Specific Fuel Oil Consumption (SFOC)

Consumption of fuel specific or specific fuel oil in (SFOC) is the parameter offered machine work that direct contact with economic value a machine [44], because with know this can be counted the amount of fuel that required to produce a number of power in a while there:

$$
\mathrm{FCR}=\frac{\mathrm{vxF}_{\mathrm{F}}}{\mathrm{t}}
$$

$$
\begin{array}{ll}
\text { Where : } & \\
\text { FCR } & : \text { flow rate }(\mathrm{gr} / \mathrm{h}) \\
\rho & : \text { density fuel }\left(\mathrm{gr} / \mathrm{m}^{3}\right) \\
\mathrm{V} & : \text { the volume of fuel }\left(\mathrm{m}^{3}\right) \\
\mathrm{t} & : \text { time necessary spent fuel, } 10 \mathrm{mls}(\mathrm{h})
\end{array}
$$

$\begin{array}{ll}\text { Where : } & \\ \text { SFOC } & \text { : specific fuel consumption }(\mathrm{gr} / \mathrm{kWh}) \\ \text { FCR } & \text { : flow rate }(\mathrm{gr} / \mathrm{h}) \\ \mathrm{P} & \quad \text { : Power }(\mathrm{kW})\end{array}$

$$
\mathrm{SFOC}=\frac{\mathrm{FCR}}{\mathrm{P}}
$$


- Torque

The amount of torque magnitudes derivative is commonly used to calculate the energy generated of objects spinning on its axis

Where :

$$
\mathrm{T}=\frac{\mathrm{P} \times 60000}{2 \pi \times \mathrm{mpm}}
$$

$$
\begin{array}{ll}
\mathrm{T} & : \text { torque }(\mathrm{Nm}) \\
\mathrm{P} & : \text { power }(\mathrm{kW}) \\
\mathrm{Rpm} & : \text { rotation motor diesel }(\mathrm{rpm})
\end{array}
$$

- BMEP

Mean Effective Pressure defined as pressure effective divided a working fluid against thoraxalong steps to produce cycle work

$$
\text { BMEP }=\frac{P \times \mathrm{Z} \times 1000}{V \times 2 \times 3,14 \times \operatorname{pps} \times \mathrm{i}}
$$

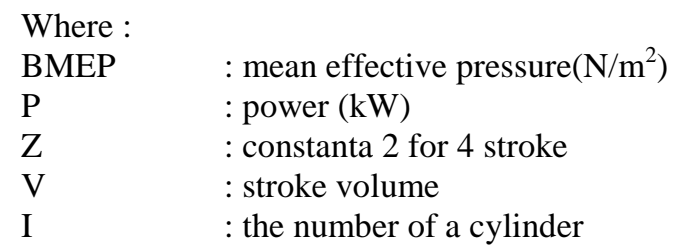

- Improvement of heat transfer performance Performance of heat exchanger is generally expressed by equation

$\begin{array}{ll} & Q=K x A x \Delta T_{m} \\ \text { Where : } & : \text { heat transfer amount }(\mathrm{W}) \\ \mathrm{Q} & : \text { thermal transmittance rate }\left(\mathrm{W} / \mathrm{m}^{2} . \mathrm{K}\right) \\ \mathrm{K} & : \text { total heat release area }\left(\mathrm{m}^{2}\right) \\ \mathrm{A} & : \text { logarithm average temperature }(\mathrm{K}) \\ \Delta \mathrm{T}_{\mathrm{m}} & \end{array}$

II.2 Manufacturing Design Cold EGR Spiral Tube System

In this process the addition of air cooling and spiral tube manufacturing is done in the Yanmar TF85 MH-di diesel motor. For the cooling system used is free air and forced air from the addition of a snail blower tool. Valve use for air exit from Exhaust Manifold using Angle Globe Valve type. And for the material used spiral pipe is Stainless. So it is expected to optimize cooling EGR

Spiral tube air temperature that will be supplied back into the Intake Manifold decreased temperature and the amount of air coming into the combustion chamber can be more. So the density of the air mass will increase At this stage of manufacturing requires some additional equipment to support in the manufacture of Cold EGR spiral tube system. Several stages such asmodification of intake and exhaust manifold on diesel motor according to required data. The addition of toolsand materials is also done at this manufacturing stage so that the EGR system in pairs can work optimally.

At this stage of manufacturing requires some additional equipment to support in the manufacture of Cold EGR spiral tube system. Several stages such as modification of intake and exhaust manifold on the diesel motor according to the required data. The addition of tools and materials is also done at this manufacturing stage so that the EGR system in pairs can work optimally.

Then performed the process of installing tools called TMR Instruments to display the results of the process of burning the machine on the computer screen. After that, the diesel motor is connected to the dynamometer as a performance test apparatus. The dynamometer output is connected to the lamp with a loading variation of 0 to 5000 watts. To know the SFOC in each loading is used Buret tool to make measurements.

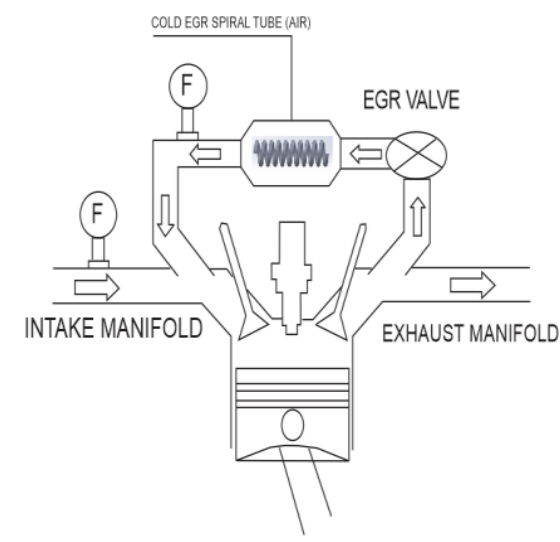

Figure. 1.Design manufacture cold EGR spiral tube

\section{II.3 Engine Set Up.}

At this stage the process of setting on diesel motors, EGR components and equipment for testing process. Conducted initial checks on the condition of diesel motors to determine the initial conditions before the research on diesel motors to be used. Arrangement on diesel motor in this research is by installing sensors which consist of Vibrasindo TMR-Card Board \& TMRCrankangleRotariEncorder on Yanmar Type TF85 MHdi diesel motor. 


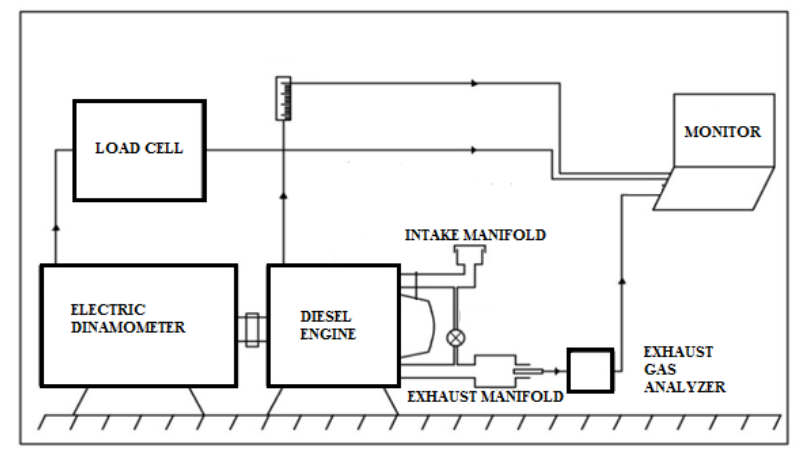

Figure. 2. Engine set up cold EGR spiral tube

a) Variable EGR Cooler:

Cooler used air

b) Variable EGR valve:

Valve type Angle Globe Valve

c) Variable EGR channel:

Channel spiral EGR system

d) Performance Test:

* Fixed Variables:

1. The fuel used pertaminadex

2. EGR spiral tube cold system

3. RPM

* Free Variable:

1. Motorcycle load (variable)

2. \% EGR valve open

e) Emissions test and combustion process:

* Fixed Variables:

1. Fuel used pertaminadex

2. EGR spiral tube cold system

3. RPM and Motorcycle Expenses (following the rules of IMO Annex VI regulation)

* Free Variable:

1. \% EGR valve open
1. Performance of diesel motors

2. The process of diesel engine combustion (pressure Ignation)

3. Data reduction of NOx levels

\section{RESULT AND DISCUSSION}

This paper review to learning theories that could support in solving the existing problems :

1. To find the performance of diesel engines using cold EGR Spiral Tube.

2. To find NOx levels of diesel engine using cold EGR Spiral Tube.

1.EGR (Exhaust Gas Recirculation)

The use of Exhaust Gas Recirculation (EGR) system has been done by recirculating some of the exhaust gases to be used again. Exhaust gases are re-utilized by the Exhaust Gas Recirculation (EGR) system itself which utilizes exhaust gas of about $10 \%-30 \%$. Then reinserted into the inlet manifold where adjusted by the EGR valve to open and close the exhaust gas into the pipeline manifold (Sorathia and Rathod)[4]. In figure 3.

f) Results Variable:

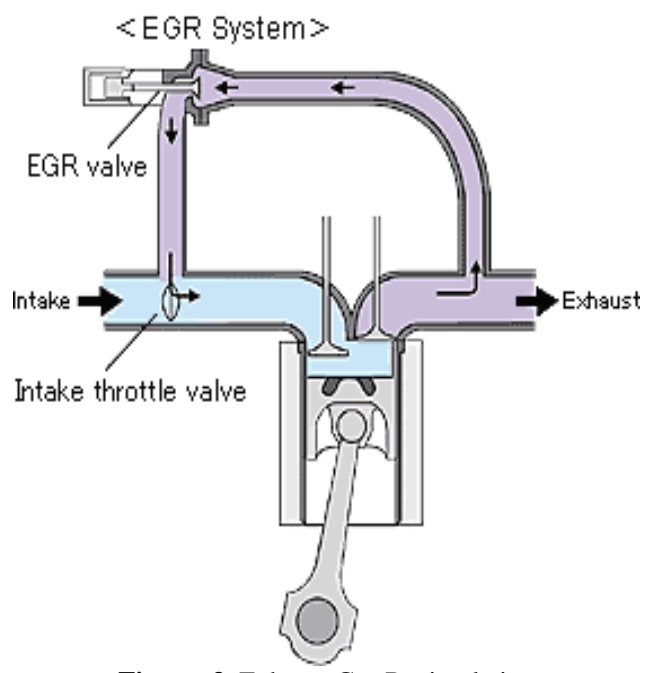

Figure. 3. Exhaust Gas Recirculation

Now there are many additional components of Exhaust Gas Recirculation (EGR) system that has been doing research. As with the addition of the use of venture scrubber and cyclonic separator in the EGR system that can reduce levels of NOx and PM. That shows that the Exhaust Gas Recirculation (EGR) system that uses the addition of a venture scrubber and cyclone separator that made diesel engines more efficient to reduce levels of NOx and PM (Dlukha,)[5].
NOx in diesel motor exhaust gas consists of $95 \%$ NO, $3-4 \% \mathrm{NO} 2$, the rest are $\mathrm{N}_{2} \mathrm{O}$ and $\mathrm{N}_{2} \mathrm{O}_{3}$. NOx substance is flavorless, but it feels painful in the eyes. The main factors affecting NOx concentrations during combustion include maximum temperature (Tmax) achieved in combustion chamber and air fuel ratio (AFR) (Darsono) [6].

In figure 4 , the use of EGR of $25 \%$ at $100 \%$ motor load, can reduce NOx concentration by $56 \%$. The use of EGR in diesel motors not only results in decreased NOx. 
However, there are some disadvantages of fuelconsumption and some emissions such as $\mathrm{HC}$, CO EGR:decreased motor performance, increased and particular (PM) (Umam)[7].

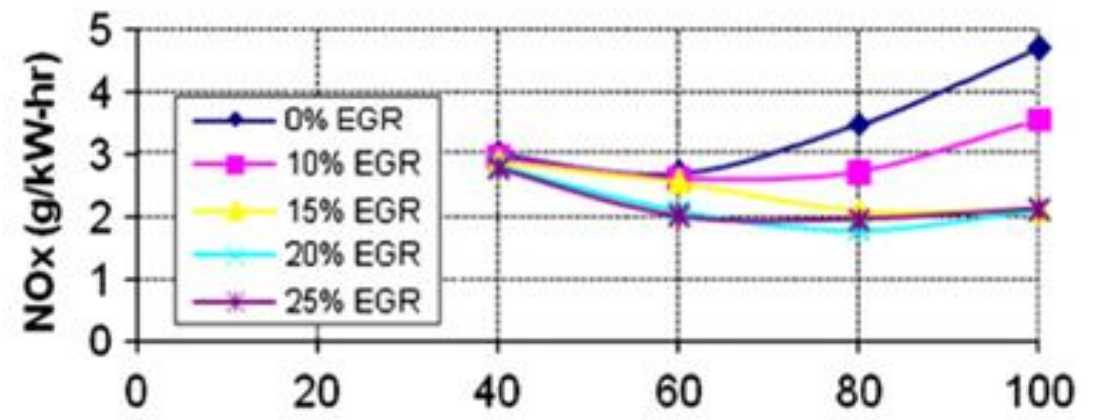

Figure. 4. NOx at different EGR rates (Umam,2009)

\section{EGR Engine Performance}

Figure 5 shows that using 30\% EGR on diesel motors will increase the brake specific fuel consumption (BSFC) by $6 \%$. In addition, the addition of EGR percentage in diesel motors resulted in Pmax andindicated mean effective pressure (IMEP) experiencing a downward trend. This results in diesel motor performance when using EGR to decline $(\mathrm{Ge})[8]$.
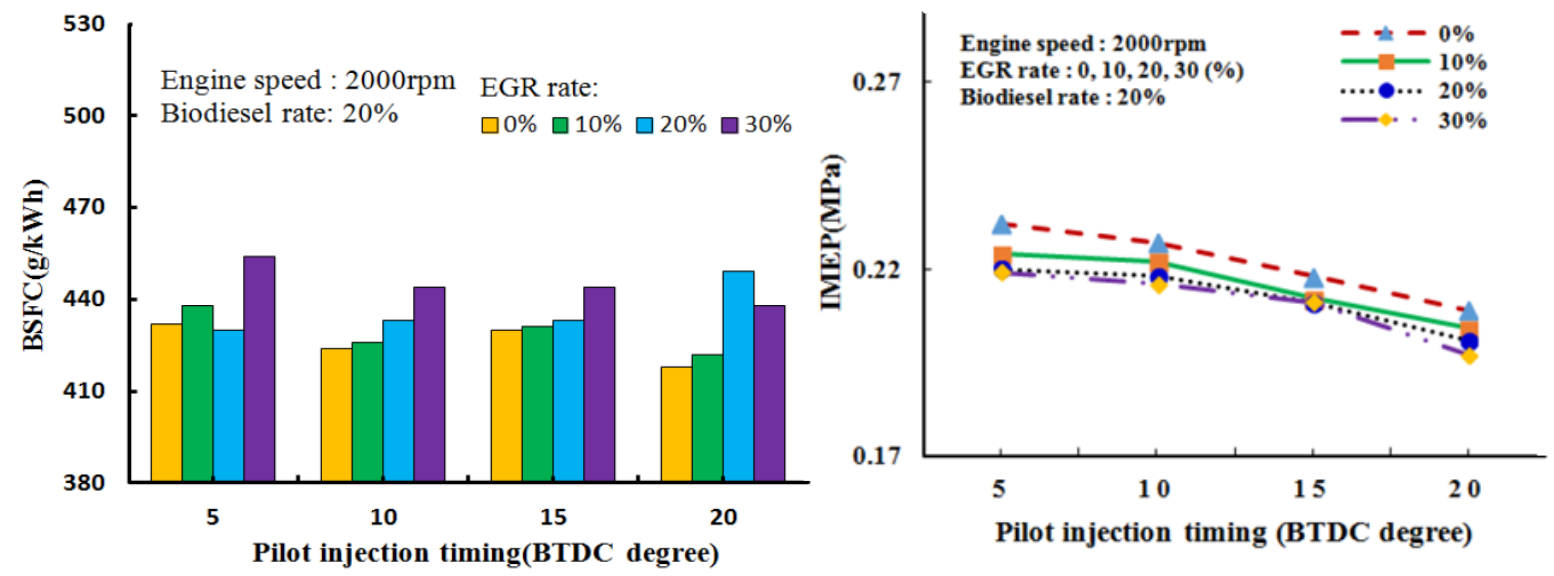

Figure. 5.BSFC and IMEP at Various EGR rates $(\mathrm{Ge}, 2015)$

Experiments conducted by K.Venkateswarulu using hot EGR along with cetane improver showed that there is significant effect on NOx emissions. Test results show that the brake thermal efficiency increases with the increase in the percentage of EGR which is accompanied by a reduction in brake specific fuel consumption and exhaust gas temperatures. There was reduction in NOx by $33 \%$ [9].

Mohamed Y.E. Selim studied the effects of EGR ratio, engine speeds, loads, temperature of recycled exhaust gases, intake charge pressure and engine compression ratio on combustion noise and thermal efficiency and observed that Exhaust gasrecirculation at an EGR ratio of $5 \%$ has a positive effect on increasing the thermal efficiency. The use of a low EGR ratio of 5\% is also favorable for reduced combustion noise and reduced $\mathrm{NOx}$ emission. However, increasing the EGR reduces the thermal efficiency. The hot EGR increases the pressure rise rate at all loads and at all EGR ratios used as compared with cooled EGR [11].

The use of EGR also affects the process of burning diesel motors. The effect of EGR on combustion process is combustion pressure and heat release rate (HRR) will decrease and duration of ignition delay becomes length.

Experimental investigations by N.Ladommatos, et.al. analyzed and quantified the principle constituents of EGR, viz. carbon dioxide and water vapour. The effect of increased inlet temperature and thermal throttling of inlet charge, both arising from the use of the hot EGR, were also investigated [10].

Figure 6 shows that the change of EGR rate from 0 $30 \%$ to the diesel motor causes combustion pressure (Mpa) and heat release $(\mathrm{kJ})$ to decrease $(\mathrm{Ge}),[8]$. 


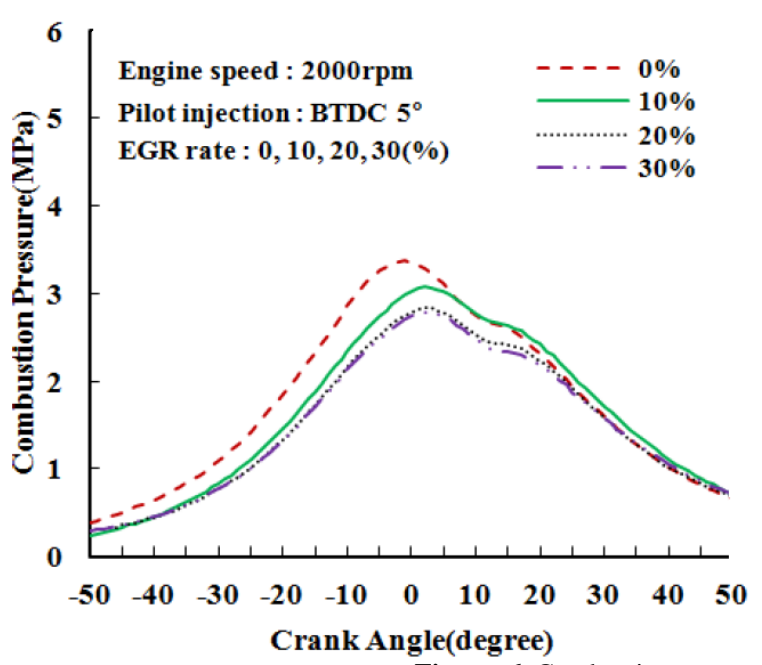

Figure. 6. Combustion pressure and HRR at various EGR rates $(\mathrm{Ge}, 2015)$

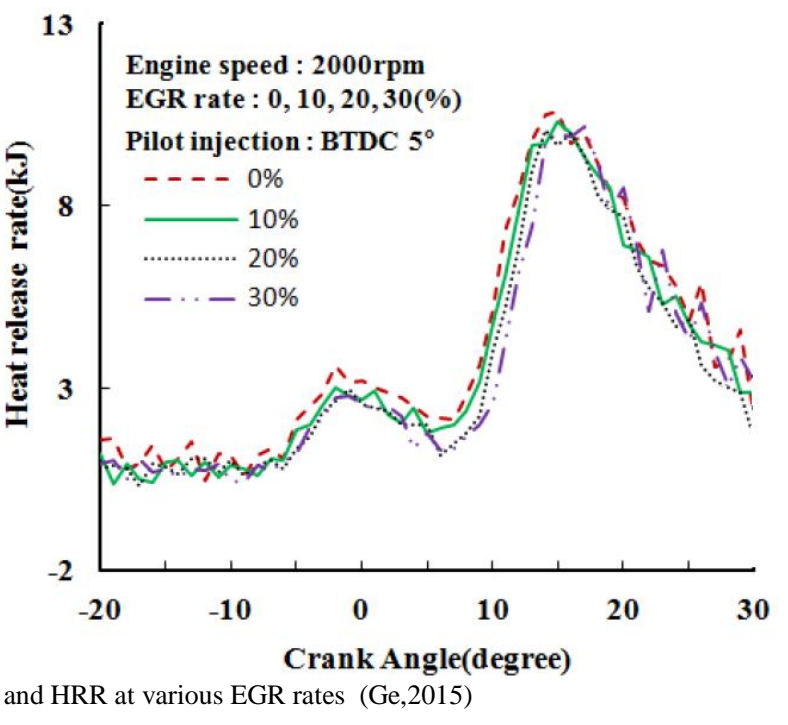

E. Kazuya Ishiki, et.al. studied on the mechanism of wear induced by soot in the EGR gas. The piston ring of the test engine was chrome plated and the cylinder was made of boron steadite cast iron. Detailed observations of the ring sliding surfaces and that of the wear debriscontainedin lubricating oil were carried out. It was found that the wear of the top ring sliding surfaces identify abrasive wear without respect to the presence of EGR by steadite on the cylinder liner sliding surface. In addition, it was confirmed in a cutting test that soot mixed lubricating oil improved in performance as cutting oil. Based on these results, it was proposed that the ring wear is accelerated at EGR because abrasive wear increases due to a lot of soot mixed into lubricating oil improving the performance of lubricating oil as cutting oil [12].

MukeshRameshbhaiZala, in his study on "Optimization of EGR Rate on multi cylinders 4 stroke diesel engine" they conducted an experimental study on a naturally aspirated 4 cylinders, 4 stroke diesel engine with modification to run with EGR. Engine performance and emission was tested at varying EGR Rate (0-40\%) and optimum EGR Rate for the naturally aspirated engine is found out by taking the performance and emission readings at varying load conditions (0-120\%) and at 1500 RPM. Brake power was measured with electric dynamometer. The evaluation of experimental data showed that NOx emission was reduced by about $80 \%$ because of EGR. [13].

Avinash Kumar Agrawal, at.al, in their study on "Effect of EGR on the exhaust gas temperature and exhaust opacity in compression ignition engines" they conducted an experimental study on a INDEC Engines Ltd make two cylinder, direct injection, rated capacity $9.3 \mathrm{~kW}$ at speed $1500 \mathrm{rpm}$, air-cooled diesel engine. The objective is to investigate and demonstrate the effects of various EGR rates on exhaust emissions from the engine. A long route partially cooled EGR system was choosen. Experiments were carried out by using a setup to prove the efficiency of EGR as a technique for NOx reduction. It is seen that the exhaust gas temperatures are reduce drastically by employing EGR. [14].

Hussain. J, Palaniradja. K,Alagumurthi.N, Manimaran.R, in their study on "Effect of Exhaust Gas Recirculation (EGR) on Performance and Emission of a Compression Ignition Engine with Staged Combustion
(Insertion of Unburned Hydrocarbon)" they conducted an experimental study on a two cylinder 4 Stroke, $52 \mathrm{HP}$, $1500 \mathrm{rpm}$ constant speed diesel engine generator set to study the effect of EGR on the performance and emissions of diesel engine components. The results were shown that UHC can be reduced by 20 to $25 \%$ from this method [15].

V.Manieniyan and S.Sivaprakasam, in their study on "Experimental Analysis of Exhaust Gas Recirculation on DI Diesel Engine Operating with Biodiesel" they used EGR technique in the diesel engine with B20 biodiesel as fuel. Madhua oil is used to prepare the biodiesel for investigation of a four stroke, water cooled, single cylinder, direct-injection (DI), vertical diesel engine running at a rated power of $5.2 \mathrm{~kW}$ and at a rated speed of $1500 \mathrm{rpm}$ coupled to an Eddy current dynamometer with EGR and without EGR at various level (5\%, 10\%, $15 \%$, and $20 \%$ ). The result shows that NOx emission is reduced using EGR for diesel and bio diesel [16].

DonepudiJagadish, Dr.Puli Ravi Kumar, Dr.K.Madhu Murthy, in their study on "Performance characteristics of a diesel engine operated on biodiesel with exhaust gas recirculation" conducted an experimental study on a Kirloskar Oil Engines with naturally aspirated single cylinder $3.7 \mathrm{~kW}$ at $1500 \mathrm{rpm}$, water cooled diesel engine with D.C shunt dynamometer is selected for experimentation. Modifications are made for the original engine set up to work with option EGR. They found that effect of EGR is to increase the fuel consumption of the engine; EGR is the best method to reduce the NOx emission [17].

\section{EGR Reduce Emissions}

Sasaki et al. conducted experiments using EGR on direct injection gasoline engine andreported that an appropriate volume of EGR improves fueleconomy and HC emissions. This phenomenon was presumablydue to the intake temperature increase by EGR, which improved the flame propagation in the relatively lean region ofthe air-fuel mixture, which is non-uniformly distributed [18].

Kusaka et al. also found that at low loads, EGR combined with intake heating can favorably reduce THC emission withimprovement in thermal efficiency [19]. EGR was also used in a direct injection spark ignition engine as an effective way forimproving fuel 
economy[20,21]. Das et al. used EGR to reduce NOx emissions in hydrogen - supplemented SI engine withoutany undesirable combustion phenomena [22]. Sato et al. performed experiments using methanol in direct injectioncompression ignition engine and found that combustion performance becomes inferior under light load conditions becausetemperature in combustion chamber fell due to very high latentheat of methanol, thus hampering formation of combustibleair-fuel mixture [23].

An increase in inlet charge temperature always results in shorter ignition delay and may improve thermal efficiency [24] If the exhaust gas is cooled before recirculation to combustion chamber, then it is called cooled EGR. Cooling ofEGR increases the charge density therefore improves volumetric efficiency of the engine. Also, it provides additional benefitsby lowering NOx emissions to a greater extent. However,condensation of moisture present in the exhaust increasescorrosion in combustion chamber. Plee et al. reported that major influence on NOx emission is due to change in temperature rather than oxygen availability [25] investigated.

Numerous experiences on different EGR systems of heavy diesel engines, in scope of measuring performance affections,special fuel consumption and pollution, reveal that cold EGR(synthesis of high pressure exhausted gases and high pressureinput air) or in other words short circuit EGR method witha variable venturi, with increased injection pressure (commonrail) and turbocharger using, in comparison with the low pressure EGR system (synthesis of hot exhausted gases and inputair before turbocharger), or in the other words long circuitEGR system, is more effective for $\mathrm{NO}_{\mathrm{X}}$ reduction and obtaining minimum amount of increased specific fuel consumption.Also short circuit EGR obstructs sediments in compressorand intercooler (if there is); in other side retardation of injection, increases the specific fuel consumption [26,27].

The level of emissions from vehicles can be reduced by establishing strict emissions standards and making sure that the vehicles continue to meet these standards throughout their useful life. In order to comply with these emissions regulations, either more advance after treatment emissions control devices have to be incorporated into the vehicle or to use some alternative fuels which are capable of providing cleaner combustion. Alternative fuels are found to have good potential in solving the diesel particulate problem, reducing the overall toxic emissions problem from vehicles, and helping to reduce urban $\mathrm{CO}$ and ozone levels [28].

The engine operates using the diesel cycle. In very cold weather, diesel fuel thickens and increases in viscosity and forms wax crystals or a gel. This can make it difficult for the fuel injector to get fuel into the cylinder in an effective manner, making cold weather starts difficult at times, though recent advances in diesel fuel technology have made these difficulties rare. A commonly applied advance is to electrically heat the fuel filter and fuel lines. Other engines utilize small electric heaters called glow plugs inside the cylinder to warm the cylinders prior to starting. A small number use resistive grid heaters in the intake manifold to warm the inlet air until the engine reaches operating temperature. Engine block heaters plugged into the utility grid are often used when an engine is shut down for extended periods in cold weather to reduce startup time and engine wear.

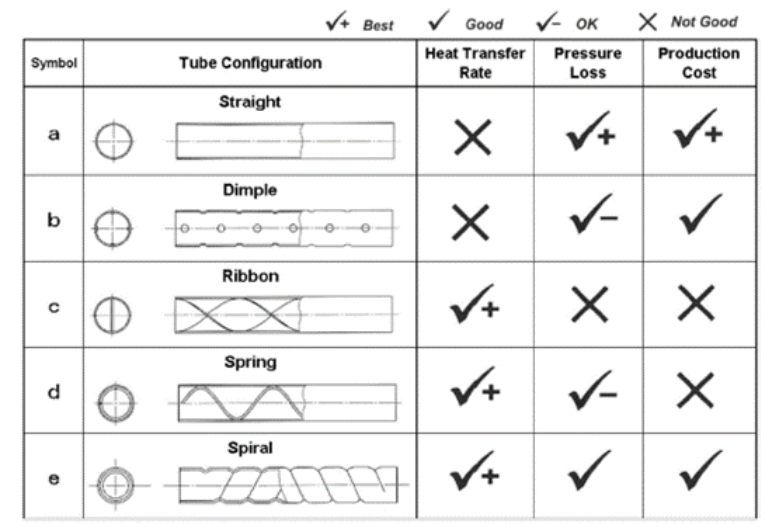

Figure. 7.Tube efficiency at heat transfer, pressure loss, and production cost (Nasser Ghassembaglou, 2016)

Unlike a gasoline engine, the incoming air is not throttled, so the engine would overspeed if this was not done. Olderinjection systems were driven by a gear system from the engine [29-30].

Semin et al. [31- 39] stated that in recent years, rising fuel prices, declining market conditions and environmental issues in terms of air emissions.

\section{EGR design and manufacture.}

One of important sections of cold EGR design is designing and manufacturing of heat exchanger for gas cooling, whichsince now will be called EGR cooler. EGR coolers are mostlyin shell-tube type. in this case gas flows through tubes andcoolant (engine jacket water) flows into the shell. This facilitates tubes cleanings and controlling of cooler exhausted gastemperature [40- 41].

The cooling process in the EGR system is a very important component. The function of this cooling is to return the exhaust gas from the exhaust with a cooler temperature so that it can lower the levels of NOx. And the oxygen mass that enters the combustion chamber has increased.

Simulation of manufacturing design ever conducted in Cold EGR system by using spiral pipe can reduce pressure drop, and also reduce heat transfer exhaust gas flow by $10 \%$ [42].

As a benchmark in the research process, the required threshold value of exhaust emissions of diesel motors. 
In the International Shipping rules, the exhaust gas emission in the main driving force must be below the set threshold. The exhaust gas threshold refers to the regulations issued by IMO MARPOL Annex VI namely:

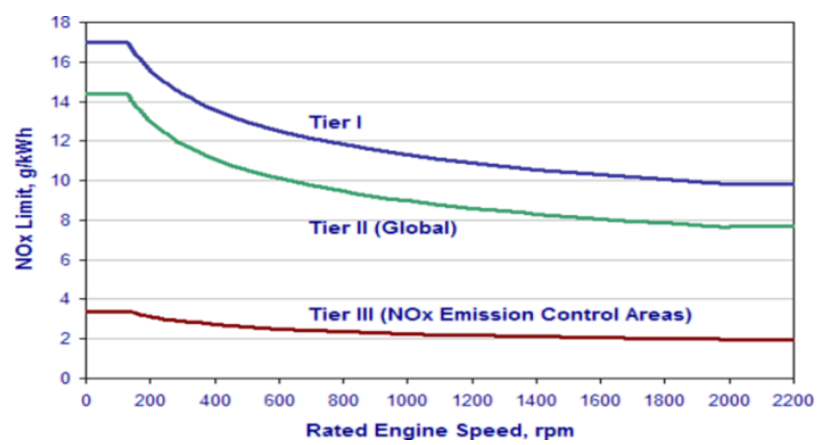

Figure. 8. MARPOL Annex VI, NOx content limit (PM No 29, article 30, 2014)

While on National Shipping, the exhaust gas emission contents generated by the main propulsion motors of the vessel have been regulated in the Minister of Transportation Decree no 29 of 2014, article 30, where every ship with gross tonnage GT 100 to GT 399 has a

\section{CONCLUSION}

The use of an EGR system with a cooler is more efficient than the use of EGR without cooling.Optimizing EGR system by adding cooling the air (cold EGR) emission levels NOx produced on motor diesel can be reduced to $18,6 \mathrm{~g} / \mathrm{kit}(52,7 \%)$. In the broad emission levels motor diesel who had EGR capable of repaired until it enters at specifications tier 2 .While on condition $30 \%$ EGR with $100 \%$ load emission levels capable of being reduced to enter threshold allowed by tier 3 .

\section{REFERENCES}

[1]. Hountalas, D. T., Mavropoulus, G.C., \& Binder, K.B. (2008). Effect of exhaust gas recirculation (EGR) temperature for various EGR rates on heavy duty DI diesel engine performance and emissions. Energy, 33(2), 272-283.

[2]. P.Saichaitanya, dkk. 2013. Impact of Cold and Hot Exhaust Gas Recirculation on Diesel Engine, Internasional Journal of Engineering Research and Applications Vol. 3, Issue 5, Sep-Oct 2013, pp.430-434

[3]. Nasser, Ghasembaglou, dkk 2016. Efficiency Design of Exhaust Gas cooler in Cold EGR equipment diesel engine. Alexandria Engineering Journal (2016) 55, 769-778

[4]. Soratha S., Harilal, Rahhod P., Pravin, 2012. Effect Of Exhaust Gas Recirculation(EGR) On NOx Emission From C.I. Engine. Review Study. India.

[5]. Dlukha, Samsu. 2012. Studi experimental penggunaanventuri scrubber dancylonicsaparatoruntukmeningkatkankinerjapada system exhaust gas recirculation (EGR) dalammenurunkanNOxpada motor diesel. ITS-PAPER. Surabaya

[6]. Darsono D., 2010, "Simulasi CFD Penggunaan EGR terhadap Performa danEmisi Gas Buang Motor Diesel” FT-UI, Indonesia

[7]. Umam, khoirul. 2009. Optimalisasirasioexhaush recirculation (EGR) padaberbagaipembebanan motor diesel denganpemodelansimulasi. ITS-PAPER. Surabaya.

[8]. Ge J.C., Min S.K. , Sam K.Y. and Nag J.C., 2015, "Effects of Pilot Injection Timing and EGR on Combustion, Performance and Exhaust Emissions in a Common Rail Diesel Engine Fueled with a Canola Oil Biodiesel-Diesel Blend" Division of Mechanical Design Engineering, Chonbuk National University, Korea.

[9]. K. Venkateswarlu, "Effect of Exhaust Gas recirculation and ethyl hexyls nitrate additive on bio diesel fuelled diesel engine for the reduction of Nox Emissions", Frontiers in Energy, July 2012, Vol. 2095-1698.

[10]. N.Ladommatos, S. Abdelhalimand H. Zhao,Control of Oxides of nitrogen from diesel engines using diluents which diesel motor under $130 \mathrm{~kW}$ sailing In Indonesian waters shall comply with the provisions of this Ministerial Regulation. (PM No 29, article 30, 2014).[43]

minimizing the impact on particulate pollutants,Applied Thermal Engineering, vol. 18, Issue 11,November 1998, pp 963-980, 1998

[11]. Mohamed Y.E. Selim, Effect of exhaust gas recirculation on some combustion characteristics of dual fuel engine, Energy Conservation and Management, vol.44, pp 707 -721, 2003

[12]. E. Kazuya Ishiki, Shinji Oshida and Masaaki Takiguchi, "A Study of Abnormal Wear in Power Cylinder of Diesel Engine with EGR - Wear Mechanism of Soot Contaminated in Lubricating Oil", SAE: Proceedings of SAE 2000 World Congress, March 2000, SAE Technical Paper No. 2000 - 01 0925, 2000.

[13]. MUKESH RameshbhaiZala, „Optimization of EGR Rate on multi cylinders 4-stroke diesel engine ${ }^{e e}$ International Journal of Engineering Research \& Technology (IJERT) Vol. 1 Issue 4 June - 2012 ISSN: 2278-0181.

[14]. AVINASH KUMAR AGRAWAL, SHRAWAN KUMAR SHAILENDRA SINHA and MRITUNJAY KUMAR SHUKLA "Effect of EGR on the exhaust gas temperature and exhaust opacity in compression ignition engines" Sadhana Vol. 29, Part 3 , June 2004, pp. 275-284

[15]. Hussain. J, Palaniradja. K, Alagumurthi.N, Mani- maran.R, “ Effect of Exhaust Gas Recirculation (EGR) on Performance and Emission of a Compression Ignition Engine with Staged Combustion (Insertion of Unburned Hydrocarbon)" International Journal of Energy Engineering 2012, 2(6): 285-292 DOI: 10.5923 / j.ijee.20120206.03

[16]. V.Manieniyan and S.Sivaprakasam, "Experimental Analysis of Exhaust Gas Recirculation on DI Diesel Engine Operating with Biodiesel" International Journal of Engineering and Technology (IJET) - Volume 3 No. 2, February, 2013.

[17]. DonepudiJagadish, Dr.Puli Ravi Kumar, Dr.K.Madhu Murthy [6], in their study on "Performance characteristics of a diesel engine operated on biodiesel with exhaust gas recirculation" International Journal of Advanced Engineering Technology. IJAET/Vol.II/ Issue II/April- June, 2011/202-208, E-ISSN 09763945.

[18]. S. Sasaki, D. Sawada, T. Ueda, H. Sami, Effect of EGR on direct injection gasoline engine, JSAE Rev. 19 (1998) 223-228.

[19]. J. Kusaka, T. Okamoto, Y. Daisho, R. Kihara, T. Saito, Combustion and exhaust gas emission characteristics of a diesel engine dual-fueled with natural gas, JSAE Rev. 21 (2000) 489496.

[20]. Y.-L. Bai, Z. Wang, J.-X. Wang, Part load characteristics of direct injection spark ignition engine using exhaust gas trap,Appl. Energy 87 (2010) 2640-2646.

[21]. G. Fontana, E. Galloni, Experimental analysis of a spark ignition engine using exhaust gas recycle at WOT operation,Appl. Energy 87 (2010) 2187-2193.

[22]. L.M. Das, R. Mathur, Exhaust gas recirculation for NOx contro in a multi-cylinder hydrogen supplemented S.I. engine, Int. J. Hydrogen Energy 18 (12) (1993) 1013-1018. 
[23]. Y. Sato, A. Noda, T. Sakamoto, Combustion control of direct injection methanol engine using a combination of charge heating and exhaust gas recirculation, JSAE Rev. 16 (1995) 369-373.

[24]. N. Ladommatos, R. Balian, R. Horrocks, L. Cooper, The effect of exhaust gas recirculation on combustion and NOx emissions in a high-speed directinjection diesel engine, in:SAE 960840, 1996.

[25]. S.L. Plee, T. Ahmad, J.P. Myers, G.M. Faeth, Diesel NOx emissions - a simple correlation technique for intake air effects, in: 19th Int. Symp. Combust, The Combustion Institute, 1982, pp. 1495-1502.

[26]. A.J.Torregrosa,P.Olmeda, J. Martın, B. DegraeuweExperiments on the influence of inlet charge and coolant temperature on performance and emissions of a DI Diesel engine, Exp. Therm Fluid Sci. 30 (2006) 633-641

[27]. R. Zhang, F. Charles, D. Ewing, Effect of diesel soot deposition on the performance of exhaust gas recirculation cooling devices, SAE, 2004 01-0122.

[28]. Bakar, R. A., Semin, Ismail, A. R., Ali, I., Computational Modeling of Compressed Natural Gas as an Alternative Fuel for Diesel Engines Proceeding of the $2^{\text {nd }}$ ANGVA Conference, Bangkok, Thailand 2007.

[29]. Bakar, Rosli.A.,Semin., The internal combustion engine diversification technology for the future: A Review, International Seminar IMarEST-ITS, Surabaya Indonesia, November 3, 2006.

[30]. Bakar, Rosli.A., Semin., Ismail, Abdul.R., The internal combustion engine diversification technology and fuel research for the future: A Review, AEESEAP Regional Symposium on Engineering Education 2007 Kuala Lumpur Malaysia, February 14, 2007.

[31]. Semin, R.A. Bakar and A.R. Ismail, 2008a. Computational visualization and simulation of diesel engines valve lift performance using CFD. Am. J. Applied Sci., 5:532539. DOI: $10.3844 /$ ajassp.2008.532.539

[32]. Semin, A.R. Ismail and R.A. Bakar, 2008b. Comparative performance of direct injection diesel engines fueled using GAS based on GT-POWER simulation. Am. J. Applied Sci., 5: 540547. DOI: 10.3844/ajassp.2008.540.547

[33]. Semin, R.A. Bakar and A.R. Ismail, 2008c. Investigation of diesel engine performance based on simulation. Am. J. Applied Sci., 5: 610-617. DOI: 10.3844/ajassp.2008.610.617

[34]. Semin, A.R. Ismail, R.ABakar and I. Ali, 2008d. Heat transfer investigation of intake port engine based on steady-state and transient simulation. Am. J. Applied Sci., 5: 1572-1579. DOI: 10.3844/ajassp.2008.1572.1579

[35]. Semin, A.R. Ismail and R.A. Bakar, 2008e. Investigation of GAS engine intake port gas flow temperature based on steady-state and transient simulation. Eur J. Scientific Res

[36]. Semin, R.A Bakarand A.R. Ismail, 2009a. Compressed natural gas as an alternative fuel for internal combustion engines: A technical review. Int. Rev. Mech. Eng.

[37]. Semin, A. Idris and R.A Bakar, 2009b. Effect of port injection GAS engine using injector nozzle multi holes on air-fuel mixing in combustion chamber. Eur. J. Scientific Res., 34: $16-24$.

[38]. Semin, A.R. Ismail and R.A. Bakar, 2009c. Gas fuel spray simulation of port injection compressed natural gas engine using injector nozzle multi holes. Eur. J. Scientific Res., 29: 188188

[39]. Semin, A. Idris, R.A. Bakar and A.R. Ismail, 2009d. Study of the engine cylinder fluid characteristics for diesel engine converted to GAS engine. Eur. J. Scientific Res.

[40]. Kazunori Takikawa, SeigiYamoto, Yuji Miyauchi, Apparatus for cooling EGR gas, United States Patent, 1999, NO.5,915,472.

[41]. Lucien Charnay, Hans-Erik Angström, Lena Andersson, CFD optimization of an EGR cooler for heavy-duty diesel engines, SAE, 2001 01-1755.

[42]. JunjiHonma, Toshiaki Murao, Youji Yamashita, Development of a highly efficient and reliable multi-tube EGR cooler, SAE,2004: 01-1446

[43]. IMO, Annex VI MARPOL 73/78, 1998. Regulation for the Prevention of Air Pollution from Ships and NOx Technical Code. International Maritime Organization. London.

[44] A. Z. M. Fathallah, W. Busse, and F. R. Clausthaldi, "Fluid Flow Analysis of Jacket Cooling System for Marine Diesel Engine 93 Kw," Int. J. Mar. Eng. Innov. Res., vol. 1, no. 2, Mar. 2017. 